\title{
Relevansi Pendekatan Kultural Linguistik Dengan Pluralitas Agama di Indonesia
}

\author{
Eko Kurniawan Wibowo \\ Pusat Studi Agama-agama (PSAA) Universitas Kristen Duta Wacana \\ ekoposmo77@gmail.com
}

\begin{abstract}
Indonesia is a plural state. Not only ethnicity, race and group, but also plural in religion where religious plurality is also a separate problem. The problem of religious plurality raises many problems that cause friction in life together. The linguistic cultural approach offered by George A. Lindbeck provides an alternative for relations for believers of diverse religion. Lindbeck's offer consistently provides space for the identity of the believer's faith without having to equate with the faith of other religions. Likewise, consistently provide space for appreciation for other religious faiths.
\end{abstract}

Keywords: plural, pluralism, linguistic cultural approach, George Lindbeck, faith identity, appreciation

Abstrak: Indonesia merupakan Negara yang sangat plural. Tidak hanya suku, ras dan golongan tetapi plural juga dalam agama dimana pluralitas agama juga menjadi persolan tersendiri. Persoalan pluralitas agama tersebut menimbulkan banyak permasalahan yang menimbulkan gesekan dalam kehidupan bersama. Pendekatan kultural linguistik yang ditawarkan George A Lindbeck memberikan alternatif bagi relasi bagi pemeluk agama yang sangat majemuk tersebut. Tawaran Lindbeck tersebut tetap memberikan ruang bagi identitas iman umat, tanpa harus menyamakan iman pribadi dengan iman liyan. Pun, tetap memberikan ruang apresiasi bagi iman agama yang lain.

Kata Kunci: plural, pluralisme, pendekatan kultural linguistik, George Lindbeck, identitas iman, apresiasi

Article History

\begin{tabular}{|l|l|l}
\hline Submitted: 1 Juni 2020 & Revised: 30 Juli 2021 & Accepted: 30 Juli 2021
\end{tabular}

\section{Pendahuluan}

Tidak bisa dipungkiri Indonesia merupakan negara yang sangat majemuk. Kemajemukan tersebut tidak hanya dari banyaknya pulau-pulau yang menghasilkan budaya, bahasa dan bentuk sosialnya, juga beragamamnya agama yang eksis di Indonesia. Secara yuridis memang hanya enam agama yang diakui di Indonesia, tetapi secara de facto hampir tiap suku di Indonesia memiliki agama lokal atau kepercayaan lokal yang disebut Penghayat. Beberapa agama lokal seperti, Parmalim, Kaharingan, Sunda Wiwitan, Samin, mulai menggeliat serta berani menunjukkan eksistensinya. Pengajuan judicial review mengenai pengisian kolom agama di luar agama resmi pada tahun 2017 dan diterimanya gugatan terhadap Pemerintah mengenai legalitas agama lokal, jelas menunjukkan bahwa agama lokal masih eksis dan masih ada (banyak) pengikutnya. Berdasar kenyataan tersebut menggambarkan reaitas Indonesia yang sangat plural atau majemuk.

Pluralitas agama di Indonesia tidak bisa dianggap sepele dan diabaikan begitu saja. Agama dari dahulu dan sampai hari ini seringkali menjadi pemicu dan jalan 
masuk kerusuhan horisontal di dalam masyarakat. Kerusuhan-kerusuhan yang terjadi acapkali menggunakan jargon-jargon agama sebagai pengguat klaim kebenaran atas tindakan yang dilakukan oleh para perusuh. Kerusuhan di Ambon dengan gamblang memerlihatkan bagaimana pihak dari Kristen menggunakan istilah Laskar Kristus bagi pasukan mereka (Hasan, 2008). Pun dari kubu Islam menggunakan istilah laskar Jihad bagi pasukan Muslim. Belum lagi teriakan-teriakan yang mereka kumandangkan adalah puji dan puja bagi Tuhan, yang diteriakkan pasukan tersebut untuk membakar semangat berperang di jalan Tuhan. Kasus lain yang sangat kentara adalah peristiwa Ahok pada Pilkada di Jakarta, yang menghasilkan semangat bela agama yang terus dilestarikan sampai hari ini. Serta masih banyak kasus-kasus yang menggunakan agama sebagai jalan masuknya yang akhirnya memicu terjadinya kekerasan dan kerusuhan, bahkan sampai menimbulkan korban jiwa.

Ketegangan yang muncul acapkali disulut oleh pemahaman yang salah mengenai agama yang lain. Pemahaman yang salah tersebut menghasilkan prasangka (prejudice) yang terus dipelihara bahkan menjadi konstruk berpikir dalam komunitas keagamaan tersebut. Ditambah lagi memori kolektif yang terus menerus dipelihara dan diwariskan mengenai kesalahan, kejahatan ataupun penindasan yang pernah dilakukan salah satu agama. Dalam relasi Islam Kristen, memori kolektif yang terus didengungkan dan dipelihara adalah mengenai perang-perang salib (crusades). Dalam konteks Indonesia stigmatisasi terhadap agama yang lain seperti: agama Kristen itu agama penjajah, agama Islam itu teroris, Hindhu itu menindas kaum kecil, Budha itu Tuhannya tidak jelas dan lain sebagainya juga menjadi persoalan tambahan yang semakin mengeruhkan relasi dengan yang berbeda agama. Persoalan tersebut semakin membara dengan maraknya gerakan-gerakan keagamaan transnasional yang menekankan orisinalitas keagamaan dan kembali ke ajaran yang murni (purifikasi) seperti yang ada dalam Kitab Suci mereka. Agenda-agenda tersebut semakin menyuburkan gerakan-gerakan keagamaan yang bersifat fundamentalis, bahkan yang bersifat destruktif seperti yang dilakukan oleh para terorisme. Gerakangerakan fundamentalis keagamaan tersebut secara sadar dan terang-terangan melakukan berbagai upaya, supaya gerakan mereka mendapatkan legitimasi sebagai gerakan permurnian agama (purifikasi). Kemurnian agama yang diperjuangkan tersebut diklain sebagai upaya memurnikan dari pengaruh luar, terutama sekularisasi, sinkretisme dan modernisme.

Melihat hal yang diuraikan diatas, penulis tertarik untuk memberikan pendekatan bagi kaum beragama dalam melihat dan memahami yang lain. 
Pendekatan yang coba penulis tawarkan adalah pendekatan kultural linguistik yang digagas oleh George A. Lindbeck (Lindbeck, 1984). Pendekatan ini diberikan oleh Lindbeck atas reaksinya terhadap dua pendekatan yang berkembang dalam memahami agama-agama lain, yaitu pendekatan kognitif doktrin agama dan pendekatan ekspresi pengalaman. Pendekatan tersebut menghasilkan klaim superioritas agama dan satunya menghasilkan relativitas agama. Keduanya bagi penulis sangat membahayakan. Klaim superioritas menghasilkan pemahaman yang sangat berbahaya dalam melihat sang liyan. Sementara relativitas agama menghasilkan pemahaman bahwa semua agama benar adanya. Dalam konteks Indonesia saat ini perlu memakai pendekatan yang menekankan kekhasan agamanya dengan tetap memberikan apresiasi bagi agama lain. Dalam tulisan di bawah ini penulis mencoba melakukan tilikan terhadap pendekatan kultural linguistik dalam kaitannya pluralitas keagaamaan di Indonesia.

\section{METODE}

Penelitian ini merupakan penelitian kualitatif dengan menggunakan metode deskriptif-analitis. Metode deskriptif merupakan upaya untuk menguraikan objek kajian dimana data yang tersedia dianalisis untuk membuat evaluasi kritis atasnya.

\section{HASIL DAN PEMBAHASAN}

\section{Sekilas Tentang George Lindbeck}

Sebelum penulis memasuki percakapan tentang pendekatan kultural linguistik dan relevansinya dengan memahami yang lain dalam konteks Indonesia, saya rasa perlu sedikit kita mengetahui tentang riwayat hidup dan karya-karya dari George A. Lindbeck. Lahir pada tahun 1923 di Cina. Seorang anak dari misonaris gereja Lutheran di Jerman dan beberapa kali pindah sekolah dari Cina, Korea dan Amerika Serikat. Lindbeck menerima gelar Ph.D dari Universitas Yale. Aktifitasnya dalam dialog inter dan intra religius terlihat keaktifannya dalam dialog-dialog ekumenis, ini bisa dilihat bagaimana Lindbeck menjadi pengamat dari beberapa sesi dari konsili Vatikan II, sebagai wakil dari Lutheran World Federation (LWF). Pengalaman hidupnya sangat kompleks dan berwarana, dimana Lindbeck berhadapan dengan banyak budaya dan agama. Pengalaman berjumpa dengan yang liyan tersebut menumbuhkan semangat Lindbeck untuk senantiasa berusaha menghormati dan memahami yang lain sebagai realitas kehidupan yang senantiasa hadir dalam peziarahan hidupnya. Sang liyan itu 
butuh untuk bisa dimengerti, dipahami dan dihormati sebagai kawan-kawan seperjalanan.

Semasa hidupnya, Lindbeck sempat membuat beberapa karya dan diterbitkan dalam buku, antara lain The Future of Roman Catholic Theology pada tahun 1971 dan Infallibility pada tahun 1972. Keterlibatan Lindbeck dalam gerakan ekumenis mulai memuncak ketika menerbitkan sebuah buku fenomenal yang berjudul The Nature of Doctrine: Religion and Theology in a Postliberal Age. Dalam karya-karyanya tersebut, Lindbeck kemudian dikenal sebagai salah seorang teolog postiberal. Sebagai salah seorang teolog postliberal Lindbeck telah memberikan kontribusi dalam kaitan pendekatan model keagamaan dan ini sangat berpengaruh dalam model hubungan antar agama.

\section{Cultural Linguistic Approach}

Apa itu Cultural Linguistic Approach? Sudah sejak lama terjadi ketegangan antara kelompok ortodoks (konservatif) yang berpegang pada makna literal atau harafiah Kitab Suci sebagai ukuran (kanon) kebenaran dari agama yang diyakininya, melawan kelompok arus liberal yang sangat menekankan pada ekspresi pengalaman sebagai kebenaran pada sebuah agama. Untuk menjembatani ketegangan Linbeck mencoba memberikan tilikan yang menjembatani ketegangan tersebut. Apa yang ditawarkan oleh Lindbeck tersebut, sempat dicurigai sebagai penutup pintu dialog interreligious bahkan dianggap meremehkan kepentingan teologis agama-agama.

Penulis terlebih dahulu mencoba untuk menjelaskan tentang perdebatan antara kubu konservatif dan kubu liberal yang sering terjadi sampai saat ini. Jikalau memakai terminologi relasi agama-agama kedua kubu tersebut adalah kelompok eksklusif (konservatif) dan kelompok pluralis (liberal). Kelompok konservatif dalam memahami imannya berpegang teguh pada dogma agama secara literal dan tidak bisa salah. Kelompok ini memegang teguh pendekatan doktrin agama (literal approach) (Lindbeck, 1984). Kelompok liberal menggunakan pendekatan agama yang disebut dengan pendekatan ekspresi pengalaman (expressive-experiental approach) (Lindbeck, 1984). Secara khusus kita akan melihat kedua pendekatan tersebut di bawah ini.

Pertama, Pendekatan kognitif literal doktrinal agama (literal approach) yang biasanya disebut sebagai kelompok yang eksklusif, ortodoks atau konservatif. Penekanan pada aspek kognitif sangat ditekankan pada pendekatan kognitif literal ini. Dogma berfungsi sebagai klaim kebenaran (truth claim) yang proposisional terhadap 
realitas obyektif (Lindbeck, 1984). Dogmatika berfungsi sebagai obyek iman sebagai proposisionalisme (Lindbeck, 1984). Proposisionalisme mempunyai kedekatan dengan fundamentalisme. Dimana ini bisa dipahami bahwa kebenaran A bukanlah kebenaran B. Jadi jika Kristen benar maka Islam adalah salah (Liere, 2002).

Kelompok ini mempunyai pandangan bahwa Kitab Suci itu bermakna harafiah atau literal yang tidak bisa salah (infabilitas) dan merupakan ukuran (kanon) kebenaran terhadap segala sesuatu yang ada yang mencakup ilmu pengetahuan, sejarah, filsafat, ekonomi, politik dan lain sebagainya. Isi dari kitab suci merupakan kebenaran historis yang pernah terjadi dan jikalau ada kelompok yang mencoba meragukannya dianggap sebagai kelompok yang sesat (heresy atau bidah). Kelompok ini berkembang sangat luas di kalangan Gereja (agama yang lain juga) dan memegang teguh prinsip tersebut, baik umat atau bahkan pemimpin umat. Dalam konteks Indonesia, kelompok tersebut tidak hanya terdapat pada agama Kristen tetapi juga pada agama-agama lain. Dalam agama Islam misalnya, klaim bahwa al-Quran merupakan Wahyu yang turun langsung dari Allah kepada Nabi Muhammad untuk menyempurnakan dan meluruskan ajaran atau kitab pendahulu, dipegang oleh mayoritas umat Muslim. Klaim yang bersifat superioritas tersebut disadari atau tidak membawa mentalitas triumfalis dan eksklusif. Contoh ini bisa dilihat ketika terjadi bencana tsunami di Aceh tahun 2003. Beberapa kalangan pengkhotbah Kristen ada yang membuat pernyataan, bahwa bencana Tsunami di Aceh terjadi karena orangorang Islam di Aceh menghambat pertumbuhan orang-orang Kristen di Aceh. Karenanya Tuhan memberikan hukuman kepada masyarakat Aceh. Pun sebaliknya di kalangan Islam juga memberikan argument, bahwa sebagai serambi Mekkah, tidak seharusnya umat Kristen merayakan Natal di Aceh. Pemahaman tersebut terjadi karena cara pandang atau pemahaman terhadap Kitab Suci sebagai yang paling benar dan tidak salah, serta setiap kata harus dimaknai secara literal atau harafiah. Konsep doktrin agama yang diformulasikan dalam doktrin secara literal diterima sebagai kebenaran yang mutlak dan sesuai dengan realitas (kenyataan) yang telah, sedang dan akan terjadi. Kelompok ini bisa disebut sebagai kelompok fundementalis dimana mereka begitu ketat dalam memahami kebenaran doktrinal agama yang merupakan representasi dari Kebenaran Ilahi.

Kedua, pendekatan ekspresi pengalaman (exspressive-experiental approach). Kelompok yang menggunakan pendekatan ini berasal dari kelompok liberal. Pada abad ke 19 tradisi ilmu pengetahuan diambil alih oleh kelompok yang menggunakan pendekatan positivisme dan naturalisme. Sehingga ada upaya untuk menghapus 
segala sesuatu yang bersifat immaterial dan rohani yang merupakan fondasi dari agama. Hal immaterial dan rohani dianggap bersifat tahayul yang menghambat kemajuan umat manusia. Kecenderungan ini juga terjadi pada agama dimana agama Kristen di Eropa berangsur-angsur mulai dipinggirkan bahkan tidak diberi tempat lagi. Agama didekati dengan pendekatan positivism-empiris yang lebih menekankan pada aspek pengalaman dan bukti-bukti yang ada secara ilmiah atau asas-asas ilmu pengetahuan. Pada masa inilah para teolog-teolog liberal mulai meragukan kebenaran historis dari cerita, kejadian yang tertulis pada kitab suci. Kelompok liberal menekankan pada ekspresi pengalaman yang menggambarkan orientasi perasaan, sikap dan eksistensi (Lindbeck, 1984). Menurut Lonergan, karakter dari model teori agama yang bersifat expressive experiental adalah sebagai berikut (Lindbeck, 1984):

1. Agama yang berbeda adalah ekspresi yang berbeda atau obyektifikasi pengalaman utama yang bersifat umum.

2. Pengalaman, kesadaran, mungkin tidak diketahui pada tingkat refleksi kesadaran diri.

3. Mempresentasikan keseluruhan eksistensi manusia.

4. Pada sebagian agama, pengalaman menjadi sumber obyektifikasi norma.

Pendekatan ekspresif pengalaman ini mempunyai pendapat bahwa pernyataan dan konsep yang bisa berupa cerita-cerita, kejadian-kejadian yang ada di Kitab Suci bukanlah merupakan redaksi ilmiah, melainkan bahasa metafor yang merupakan ekspresi pengalaman spiritual pribadi dari seseorang. Maka dari itu kita perlu untuk membuktikan kebenaran obyektif dari pengalaman spiritualitas tersebut. Interpretasi terhadap teks kitab suci adalah dalam rangka mencoba mencari makna spiritualitas pada ekspresi pengalaman yang ditulis dalam kitab suci yang merupakan bahasa metafor. Sebagai contoh penyebutan Yesus sebagai Tuhan adalah penyebutan gelar yang sangat terhormat karena pengalaman spiritualitas yang mendalam dalam kehidupan Yesus sehingga para murid-murid dan pengikutnya sangat menghormatinya. Jadi pengalaman mengenai Yesus yang begitu luar biasa bisa juga terjadi di kelompok (agama) lain dengam setting tempat dan tokoh yang berbeda. Misalnya: Krisna di India, Muhammad di Jazirah Arab dan lain sebagainya. Kelompok ini mengklaim bahwa rasionalitas merupakan kunci dalam memahami setiap pengalaman dan peristiwa yang terjadi, termasuk dalam beragama.

Pandangan yang ketiga yang disampaikan oleh Lindbeck seperti yang telah sedikit diuraikan di atas adalah mencoba menjembatani ketegangan antara pendekatan konservatif dan liberal (Lindbeck, 1984). Dalam pandangan ini, agama 
dapat dilihat sebagai sebagai kerangka atau media kultural dan ataupun linguistik yang memberikan gambaran bagi keseluruhan iman dan pola berpikir pemeluknya (Lindbeck, 1984). Bahasa (linguistik) yang terdapat pada agama dapat memberi bentuk pada pikiran dan keyakinan agama kita. Tanpa bahasa religius, maka kita tidak akan memiliki perasaan religius. Bahasa agama tersebut selanjutnya memberikan bentuk khusus pada pengalaman, sehingga jika tidak ada bahasa maka tidak akan ada pengalaman. Dalam hal partikularitas, Lindbeck menyatakan bahwa tidak ada satu pun yang bisa benar-benar dikatakan sama bagi semua agama (Lindbeck, 1984). Dengan kata lain, tidak ada satu pun pengalaman religius yang sama di antara semua agama. Menurut Lindbeck kalau bahasa menciptakan dunia kita dan kalau bahasa kita berbeda-beda, maka dunia kita akan berbeda, tanpa ada asas yang sama. Jadi bahasa dan budaya tidak akan memungkinkan adanya "satu esensi eksperiensial tunggal yang universal" di dalam semua agama yang berbeda-beda (Lindbeck, 1984). Seperti yang diuraikan oleh Sugiharto bahasa-bahasa yang kita pahami tersebut berusaha kita transformasikan dunia dan dunia mentransformasikan kita (Sugiharto, 1996). Proses transformasi atau metamorfosis tersebut menghasilkan pemahaman tentang realitas. Kenyataan yang coba dipahami tersebut bukan lahir dari sesuatu yang kosong, namun lahir dan dibentuk dari cara memahami realitas yang ada termasuk dari teks suci. Teks suci yang coba dipahami tersebut menghasilkan pemahaman yang berbeda-beda (Sugiharto, 1996).

Lindbeck sangat menekankan pendekatan linguistik-kultural dalam pemikiran Pendekatan yang ditawarkan Lindbeck dapat memberikan keterbukaan pada kemungkinan perbedaan di antara agama-agama yang "tidak dapat dibandingkan" (incommensurable) dan "tak keterjemahkanan" (untranslability) (Lindbeck, 1984). Jadi, tidak mungkin untuk memahami satu bahasa agama dengan menginterpretasikan ke dalam satu bahasa agama lainnya, karena agama yang berbeda tidak mungkin diinterpretasikana menurut bahasa dan budaya agama pemeluknya. Secara sederhana pemahaman ini mau mengatakan bahwa tidak mungkin agama Islam dipahami dengan menggunakan agama Kristen dan begitu pula sebaliknya. Harus disadari setiap agama mempunyai kekhasan masing-masing, sehingga setiap agama tertentu tidak dapat dibandingkan dengan agama yang lain. Serta agama lain tidak mungkin diterjemahkan melalui pemahaman agama yang lain. Kekhasan atau keunikan setiap agama tidak akan bisa ditemui dalam agama lain. Begitu pula kekhasan tiap agama tersebut tidak bisa dipakai menilai agama yang lain. Contoh sederhana yang bisa diungkapkan adalah pengakuan Yesus sebagai Tuhan adalah 
bahasa yang sangat khas dari iman Kristen. Kekhasan ataupun keunikan tersebut bisa dipahami dengan memakai bahasa Iman Kristen, yaitu Allah yang berfirman dan Firman itu menjadi manusia. Bahasa atau yang khas dari Kekristenan tersebut tidak akan bisa dipakai dalam menilai keesaan Allah dalam agama Islam (tauhid). Begitu pula sebaliknya keesaan Tuhan dalam Islam tidak bisa dipakai menilai Firman Allah yang menjadi manusia. Lindbeck memahami agama mempunyai keunikan sendiri yang tidak dapat dibandingkan dengan agama yang berbeda. Begitu pula setiap agama tak-keterjemahkanan atau tidak bisa diintrepretasikan dengan kacamata dari agama yang berbeda.

Ini bisa dilihat secara lebih luas lagi. Ada kata-kata yang sama dipakai dalam berbagai agama, misalnya kata kasih atau Tuhan. Persamaan kata-kata tersebut sebetulnya mempunyai makna yang berbeda dalam setiap agama. Agama dan pengalaman beragama bisa dimengerti dan diyakini sebagai "benar" hanya di dalam teks tertentu atau di dalam sistem bahasa dari agama tertentu sehingga kata kasih atau Tuhan yang dipahami agama Buddha menjadi berbeda dengan kata kasih atau Tuhan yang dipahami agama Kristen. Menurut pandangan Lindbeck, untuk mengetahui suatu agama, maka seseorang harus memahami kata-kata dalam agama tersebut (Lindbeck, 1984). Apabila seseorang telah menjadi seorang Kristen, maka harus mempelajari bahasa kekristenan itu sendiri dan sistem simbolis dari kekristenan. Bagi orang Kristen, ada dua kata penting yang digunakan yaitu hanya Kristus (solus Christus) (Lindbeck, 1984). Jadi bagi Lindbeck, orang Kristen hanya dapat berbicara dan berkata-kata secara benar di dalam bahasa "khusus" Kristen yaitu "hanya Kristus". Dengan kata lain, ini menunjukkan bahwa tidak ada keselamatan tanpa Kristus. Namun demikian, istilah solus Christus tidak menyangkali bahwa ada kemungkinan keselamatan bagi orang non-Kristen (Lindbeck, 1984). Dengan kata lain, istilah tersebut tidak berarti bahwa orang Kristen harus mencoret agama-agama lain atau mengabaikan nilai-nilai agama lain. Lindbeck mengakui bahwa meskipun Kristus merupakan saluran keselamatan satu-satunya, namun agama lain mungkin merupakan anak-anak sungai penting yang mengalirkan air ke dalam saluran tersebut (Lindbeck, 1984). Oleh karena itu, bagi Lindbeck, tugas misioner orang Kristen adalah selalu mendorong orang Yahudi, Muslim, Buddha, Hindu untuk menjadi orang Yahudi, Muslim, Buddha, dan Hindu yang baik. Secara sederhana dapat dikatakan bahwa agama adalah soal apa yang dilakukan, agama adalah sebuah praktek tindakan yang diwujudkan dalam kehidupan sehari-hari berdasarkan apa yang manusia percayai. Dengan demikian, pemikiran Lindbeck ini menggambarkan bahwa agama-agama di 
dunia memang sangat berbeda dan hubungan di antara agama tersebut haruslah di bangun atas dasar mengakui, menghargai, dan belajar dari semua perbedaan yang ada (Lindbeck, 1984).

\section{Memahami Yang Lain}

Istilah memahami (verstehen) menurut Budi hardiman berbeda dengan mengetahui, kata mengetahui ini menyiratkan kemampuan diri kita untuk merasakan sesuatu pengalaman yang dimiliki oleh orang lain (Hardiman, 2015). Lebih lanjut Hardiman menjelaskan bahwa proses memahami tidak bersifat berjarak tetapi hadir dan ikut mersakan untuk bisa menemukan makna. Jadi bisa dikatakan proses memahami dengan menggunakan bahasa Dunne adalah sebuah proses passing over. Proses tidak berjarak dan sungguh-sungguh hadir disitu diperlukan untuk benar-benar tahu dengan baik bahasa dan budaya yang digunakan yang lain tersebut. Proses memahami tersebut berhubungan dengan hermeneutik. Hermenutik secara umum bisa dikatakan mencoba memahami bahasa ataupun budaya yang lain ke dalam bahasa kita dan mencoba untuk mengartikulasikan pemahaman kita kepada orang lain (Hardiman, 2015). Proses hermeneutik sendiri menurut sejarahnya tidak hanya upaya memahami teks-teks suci saja tetapi memahami dalam arti yang lebih luas yaitu horizon ontologis dan antropologis (Hardiman, 2015). Jadi memahami merupakan sebuah tindakan yang tidak bisa diabaikan begitu saja, terlebih dalam memahami keagamaan yang lain, yang pasti memiliki kekhasan masing-masing. Lebih lagi dalam konteks Indonesia proses memahami perlu dilakukan dengan sungguh-sungguh mengingat negara Indonesia yang sangat majemuk.

Pluralitas di Indonesia merupakan kenyataan yang harus disadari dan dikelola dengan baik. Pengelolaan tersebut tidak hanya bersifat pengakuan saja bahwa ada perbedaan di sekitar kita (Indonesia), tetapi penghargaan, penghormatan dan kesetaraan dengan yang berbeda di sekitar kita. Di dalam pendahuluan telah disebutkan kenyataan kemajemukan tersebut sangat berpengaruh dalam kita berelasi dengan yang lain. Relasi dengan yang lain tersebut bisa kita lakukan dengan baik selain adanya sistem undang-undang yang baik juga kesadaran untuk mau memahami yang lain. Persoalan tentang yang lain tersebut akan semakin sensitif ketika menyangkut perbedaan agama. Jika kita tidak sungguh-sungguh memahami yang lain agama tersebut akan terus menimbulkan ketegangan yang bisa mengakibatkan gesekan-gesekan. Gesekan yang terjadi akan semakin memanas jikalau diperhadapakan pada truth claim masing-masing agama. Dalam konteks Indonesia, 
dimana penduduknya banyak yang memeluk agama Islam, sering berbenturan dengan Kekristenan yang memang mempunyai akar permusuhan sejak lama.

Akar permusuhan antara Islam Kristen akan terus berkembang jikalau kita tidak pernah berusaha untuk memahami secara sungguh-sungguh apa yang menjadi pokok permasalahannya. Pokok permasalahan tersebut justru bisa menjadi dogma yang mengikat setiap pemeluk agama untuk melegalkan setiap tindakan kekerasan terhadap yang lain. Pemahaman yang proposisional bukankah mengajarkan bahwa kita yang benar di luar kita adalah salah. Pemahaman bahwa dalam agamanya saja terdapat kebenaran yang mutlak dan agama yang lain salah merupakan sikap eksklusivisme dari banyak orang dalam beragama (Panikar, 1994). Terjebak pada pemahaman yang seperti itu niscaya hubungan antara umat beragama jauh dari situasi rukun dan damai. Begitu pula dengan pemahaman yang mengatakan bahwa agamamu sama dengan agamaku, jadi kita tidak perlu repot-repot untuk mengetahui siapa yang paling benar. Prinsip bahwa tidak ada kebenaran yang sungguh-sungguh obyektif tersebut membuat agama tidak mempunyai sifat khasnya masing-masing, karena terjebak pemahaman yang merelatifkan setiap agama. Kedua hal tersebut dalam persoalan relasi dan memahami yang lain akan membawa kita pada sikap eksklusivisme ataupun relativisme.

Tantangan pola pemikiran yang eklusivisme dan relativisme tersebut sangat rawan dalam kehidupan berbangsa dan bertanah air di Indonesia yang sangat majemuk. Agama justru menjadi bahaya laten yang siap muncul kapan saja jika situasi dan kondisinya sangat menguntungkan. Sumbangan pemikiran dari Lindbeck mengenai pendekatan cultural linguistic sangat berguna dalam memahami agama sendiri ataupun melihat agama orang lain. Melalui model kultural-linguistik, Lindbeck menunjukkan bahwa setiap agama memiliki permainan bahasa-nya sendiri dan tidak bisa diukur dan disamakan dengan mudah dengan agama-agama lain. Menurut penulis apa yang diusulkan oleh Lindbeck mengajak kita untuk sungguh-sungguh melihat kekhasan dari iman yang kita miliki. Kekhasan iman tersebut merupakan bahasa iman pribadi yang juga mampu dibahasakan secara baik kepada yang lain. Untuk bisa membahasakan kekhasan agama kita, yang sungguh-sungguh harus dilakukan adalah berani untuk mencoba memahami bahasa serta budaya dari agama yang lain. Dalam kekristenan misalnya, dogma Trinitas dalam Kekristenan merupakan hasil dari pergulatan panjang dari para teolog Kristen masa lalu. Bahasa dogma masa lalu tersebut sudah menjadi dogma yang mengikat bagi Kekristenan yang harus dibahasakan dengan baik dalam lingkup Indonesia. Hal tersebut bisa terjadi, jikalau 
sungguh-sungguh mau untuk memahami tentang yang lain, seperti mencoba memahamai bahasa tauhid (keesaan Tuhan) dari agama Islam. Ketika kita sungguhsungguh memahami, tentunya dengan santun kita bisa membahasakan apa yang menjadi kekhasan iman Kristen dan memahami apa yang menjadi keunikan dari iman Islam. Dalam pendekatan kultural linguistik tersebut satu hal yang penulis garis bawahi adalah kekhasan atau keunikan tiap agama tersebut tidak bisa dijadikan ukuran dalam menilai kekhasan agama yang lain.

Proses memahami yang lain memang bukan sesuatu yang mudah. Sentimen keagamaan yang ada dalam diri kita seringkali muncul dan membuat kita terjebak dalam pemahaman yang eksklusif. Walau begitu godaan postmodern juga tidak kalah besar ketika melihat realitas keagamaan adalah sesuatu yang sama-sama benarnya. Kedua pemahaman tersebut dalam dimensi relasi tentunya akan membuat kita memegang sangat erat identitas kita sehingga menafikan yang lain. Begitu pula dengan pemahaman yang relativis akan membuat kita kehilangan identitas yang kita miliki. Berangkat dari persoalan untuk bisa menghargai yang lain, pendekatan kultrual linguistik dari Lindbeck mengajak kita untuk tetap memegang identitas tanpa mengabaikan identitas yang lain diluar kita.

\section{KESIMPULAN}

Dari pemaparan pemikiran Lindbeck mengenai pendekatan kultural linguistik yang berkaitan dengan pluralitas beragama di Indonesia, penulis memberikan beberapa tanggapan atas pemikirannya tersebut, antara lain: Pertama, harus diakui agama Kristen adalah agama yang bersifat misioner sama halnya dengan agama Islam. Persoalan penginjilan (misi) dan konversi karena pengaruh dari misi atau dakwah seringkali juga muncul ke permukaan. Tuduhan Kristenisasi atau Islamisasi membuat ketegangan hubungan kedua agama terus berjalan. Persoalan tersebut mengajak para pemeluk agama untuk mencoba memahami bahasa dari iman yang lain dan semestinya membuat para pemeluk agama sadar bahwa persoalan konversi adalah persoalan hati. Alternatif pemahaman yang disampaikan Lindbeck memang sangat sulit dikaitkan dengan persoalan hasrat untuk menobatkan yang "belum selamat" (jiwa misioner). Penulis memahami bahwa persoalan misi merupakan hal pokok yang justru kurang mendapat tilikan dari Lindbeck. Berkaca dari persoalan tersebut pemahaman misi seharusnya tidak hanya dipersempit mengenai penjangkauan saja, tetapi kebermaknaan agama dalam kehadirannya sebagai pembawa syalom/salam/harmoni/keselarasan dalam kehidupan bersama. Jadi para 
pemeluk agama saling mempromosikan agamanya masing-masing dengan laku hidup yang menghadirkan damai bagi siapapun. Kedua, pendekatan yang ditawarkan Lindbeck dituduh bisa menutup pintu dialog dengan agama yang lain karena persoalan "tidak dapat dibandingkan" (incommensurable) dan "tak keterjemahkanan" (untranslability). Justru menurut penulis, kedua hal tersebut menjadikan dialog yang terjadi lebih autentik, proposional dan apresiatif. Bahwa dalam agama-agama yang lain, memang ada yang tidak bisa dipahami dan diterjemahkan dengan kacamata sendiri. Kenyataan tersebut membuat dialog bisa berjalan lebih autentik. Begitu pula setiap agama mempunyai kekhasan atau keunikan yang tidak dipunyai atau dimiliki agama tertentu justru memberikan ruang apresiasi dan semangat untuk memahami yang lain. Dialog interreligius yang ditampilkan justru sarat dengan keyakinan iman yang teguh dan menghargai keteguhan iman yang lain. Ketiga, Lindbeck sangat menitikberatkan pada peranan bahasa dan kata-kata. Bahasa inilah yang ia gunakan untuk menjawab situasi saat ini, khususnya dalam kaitan hubungan antaragama. Penulis setuju bahwa memang bahasa dan kata-kata yang dipakai oleh setiap agama berbeda-beda, misalnya kata kasih dan Tuhan. Namun demikian, dengan bahasa dan kata-kata yang berbeda inilah kita dapat mengenal satu sama lain dan dapat saling memperkaya pengalaman iman dari bahasa yang kita miliki masing-masing. Konteks Indonesia yang plural memerlukan kerendahan hati untuk belajar dari yang lain (the others), seperti belajar bahasa asing supaya semakin mengerti dan melengkapi. Usaha untuk memahami bahasa agama lain adalah dalam rangka untuk semakin mengokohkan identitas keimanan sendiri, bukan dalam rangka mencari titik lemah dari agama lain. Keempat, kekhasan dari tiap-tiap agama merupakan identitas iman yang unik. Kekhasan yang menghasilkan keunikan tersebut tidak bisa dijadikan ukuran (kanon) untuk menilai kekhasan agama yang lain. Seringkali kita terjebak untuk menilai yang lain dari kekhasan yang kita miliki. Tetapi dengan mencoba untuk benar-benar memahami yang lain akan membawa kita mampu memahami - walau tidak sepenuhpenuhnya - bahasa dan budaya yang lain dan mampu mengartikulasikan bahasa dan budaya tersebut menurut bahasa dan budaya kita dengan santun, tanpa harus kehilangan identitas kita dan menafikan identitas yang lain.

\section{DAFTAR PUSTAKA}

Hardiman, F. B. (2015). Seni Memahami: Hermeneutik dari Schleirmacher sampai Derida. Kanisius.

Hasan, N. (2008). Laskar Jihad: Islam, Militansi, dan Pencarian Identitas di Indonesia 
Pasca-Orde Baru. LP3ES dan KITLV.

Liere, L. van. (2002). Memutus Rantai Kekerasan: Teologi dan Etika Kristen Di

Tengah Tantangan Globalisasi dan Terorisme. BPK Gunung Mulia.

Lindbeck, G. (1984). The Nature of Doctrine: Religion and Theology in a Postliberal

Age. Westminster Press.

Panikar, R. (1994). Dialog Intra Religius (A. Sudiarja (ed.)). Kanisius.

Sugiharto, B. (1996). Postmodernisme: Tantangan Filsafat. Kanisius. 